\title{
RELEASE OF NONEXCHANGEABLE POTASSIUM FROM FINNISH MINERAL SOILS
}

\author{
ARMi KaILA \\ University of Helsinki, Department of Agricultural Chemistry
}

Received March, 21, 1967

Exchangeable potassium in soils is considered to be the main source of potassium for crops. It seems, however, that this form of potassium is not always completely available to plants: it may be depleted to a certain level, and then the potassium uptake of plants will depend on the rate of release of potassium from nonexchangeable sources (Wiessmann and Lehmann 1934, Schachtschabel 1937, Stanton and Orchard 1963). Prolonged cropping in greenhouse and successive Neubauer-tests show that, from certain soils, plants may take up large amounts of potassium which in the beginning of the experiment could not be extracted by the usual procedures for the estimation of exchangeable potassium (ABEL and Magistad 1935, Schachtschabel 1937, Keränen 1946, Stewart and Volk 1946, Reitemeier et al. 1948, Gholston and Hoover 1949, Breland et al. 1950 etc.). Thus, the agreement between the content of exchangeable potassium in the soil and the results of field and pot experiments is often poor, and a better index to the potassium supplying power of the soil may be obtained, if, in addition to the exchangeable potassium, also the more readily releaseable nonexchangeable potassium is taken into account (Keränen 1946, Gholston, and Hoover 1949, Schmitz and Pratt 1953, Egnér 1954, Semb and Uhlen 1955).

According to ARNold (1960), this monexchangeable but useful potassium» is held in the outer parts of the crystal lattice of clay minerals, and it may be native soil potassium, or it may have accumulated from fertilizers. Potassium held deep within the crystal lattice of clay minerals or in coarse material will be released first when the minerals will weather, and it represents the inert fraction of potassium.

Prolonged cropping of a soil in greenhouse is a laborious procedure for the determination of the release of nonexchangeable potassium. Instead of it rapid chemical tests are used in which the soil samples are extracted for a shorter or a longer period 
with mineral acid, often at a higher temperature. Although it is not likely that these chemical and biological methods will determine quite identical forms of potassium, the results are usually of the same order and fairly closely correlated (REITEMEIER et al. 1948, Rouse and Bertramson 1949).

Extraction with acid was used also in the present study to get an estimate of the useful potassium reserves in Finnish mineral soils. The soil samples were also analysed for their content of readily exchangeable potassium and for their capacity to fix added potassium under "wet" conditions. A part of the latter results has been published in a previous paper (KAILA 1965). Attention was also paid to the retention of applied potassium during incubation in the laboratory.

\section{Material and methods}

The material consisted of 330 samples, collected from various parts of the country. 161 samples were from the surface layer down to $15-20 \mathrm{~cm}$, and 169 samples represented deeper layers, mostly between the depths of $20 \mathrm{~cm}$ and $70 \mathrm{~cm}$. The samples were mainly from cultivated soils: only 26 samples of the surface layers and 54 samples of the deeper layers were from virgin lands.

The samples were air-dried and ground to pass the $2 \mathrm{~mm}$ sieve. Thus, in most cases the moraine soils will be listed as sand and fine sand, when the samples are grouped according to the mechanical composition into the textural classes used in Finland.

Soil $\mathrm{pH}$ was measured in 1:2.5 suspension in $0.01 \mathrm{M} \mathrm{CaCl}_{2}$ by the glass electrode. Organic carbon was estimated by wet-combustion using iodometric titration.

Readily exchangeable potassium was determined by shaking $10 \mathrm{~g}$ of the sample for one hour in $50 \mathrm{ml}$ of $0.5 \mathrm{~N}$ neutral ammoniumacetate. When results obtained in this way for 60 samples were compared with data given by the usual method of washing $5 \mathrm{~g}$ of soil with $200 \mathrm{ml}$ of $1 \mathrm{~N}$ ammoniumacetate, it was found that in samples of heavy clay the readily exchangeable potassium corresponded to about 75 per cent of the amount extracted by the usual method, in samples of silty clay, sandy clay and clay loam the corresponding part was about 87 per cent, and in the nonclay samples the average percentage was 100 .

Fixation of potassium was estimated according to the procedure of SснаснтSCHABEL (1961): 2.5 me of $\mathrm{K}$ per $100 \mathrm{~g}$ of soil was added without drying.

Release of nonexchangeable potassium was determined using the acid extraction as the modification developed by Schachtschabel (1961). In this procedure $5 \mathrm{~g}$ of soil is treated with $50 \mathrm{ml}$ of $1 \mathrm{~N} \mathrm{HCl}$ at $50^{\circ} \mathrm{C}$ for 20 hours. The amount of readily exchangeable $\mathrm{K}$ was subtracted from the amount of acid soluble $\mathrm{K}$ to get the nonexchangeable $\mathrm{K}$ released by the treatment with acid. In clay soils some exchangeable potassium was left in the fraction of nonexchangeable but this error was insignificant.

According to Schachtschabel (1961), the results of this method are closely correlated with those obtained with the widely used method of boiling $\mathrm{HNO}_{3}$ extraction first introduced by WooD and DeTURK (1941). In connection with the present study a comparison was made between the amounts of $\mathrm{K}$ dissolved by treating 
the soil samples in the ratio of 1 to 10 with $1 \mathrm{~N} \mathrm{HCl}$ at $50^{\circ} \mathrm{C}$ for 20 hours or with $1 \mathrm{~N} \mathrm{HNO}_{3}$ for 10 minutes at the boiling point. In a material of 20 samples the results obtained by the $\mathrm{HCl}$-extraction ranged from 96 to 135 per cent of those found by the $\mathrm{HNO}_{3}$-method, being, on the average, about 10 per cent higher than the latter ones. The correlation coefficient between the results of the methods was $r=0.98^{* * *}$, and the equation for the regression line $\mathrm{y}_{(\mathrm{HCl})}=0.95 \mathrm{x}\left(\mathrm{HNO}_{3}\right)+65.0$. Thus, in these soils the results were of the same order, but contrary to the observations of ScHAchтSCHABEL (1961), the HCl-treatment tended to extract slightly higher amounts of potassium than did the $\mathrm{HNO}_{3}$-procedure, since the amounts extracted remained below $1300 \mathrm{mg} / 100 \mathrm{~g}$.

\section{Results}

The soil samples in the different textural groups are characterized by the data in Table 1. On the average, the samples are rather acid, except the silt, silty clay and heavy clay soils from the deeper layers. The content or organic carbon is fairly high in the surface layers. The mean content of readily exchangeable potassium appears

Table 1. Soil samples.

\begin{tabular}{|c|c|c|c|c|c|c|}
\hline & $\begin{array}{l}\text { Number } \\
\text { of } \\
\text { samples }\end{array}$ & $\mathrm{pH}^{*}$ & $\begin{array}{c}\text { Org. C } \\
\%^{*}\end{array}$ & $\begin{array}{c}\text { Clay } \\
\% *\end{array}$ & $\begin{array}{c}\text { Exchangeable } \\
\mathrm{K} \\
\mathrm{mg} / 100 \mathrm{~g}^{*}\end{array}$ & $\begin{array}{c}\text { Fixation of } \\
\text { K } \\
\%^{*}\end{array}$ \\
\hline \multicolumn{7}{|l|}{ Surface samples } \\
\hline Sand, fine sand & 42 & $5.1 \pm 0.3$ & $4.0 \pm 0.7$ & $\mathbf{9} \pm \mathbf{3}$ & $14.4 \pm 2.2$ & $11 \pm 1$ \\
\hline Loam & 34 & $5.2 \pm 0.2$ & $3.6 \pm 0.6$ & $22 \pm 2$ & $15.3 \pm 2.8$ & $12 \pm 1$ \\
\hline Silt & 19 & $5.2 \pm 0.2$ & $3.1 \pm 0.7$ & $19 \pm 3$ & $13.3 \pm 4.8$ & $15 \pm 3$ \\
\hline Clay loam & 30 & $5.3 \pm 0.2$ & $5.4 \pm 0.5$ & $40 \pm 3$ & $22.1 \pm 3.7$ & $18 \pm 3$ \\
\hline Silty clay & 28 & $5.2 \pm 0.2$ & $4.0 \pm 0.6$ & $43 \pm 3$ & $22.4 \pm 3.2$ & $20 \pm 2$ \\
\hline Heavy clay & 8 & $5.1 \pm 0.2$ & $4.8 \pm 0.6$ & $64 \pm 3$ & $25.9 \pm 7.3$ & $22 \pm 3$ \\
\hline \multicolumn{7}{|l|}{ Subsoil samples } \\
\hline Sand, fine sand & 45 & $5.0 \pm 0.3$ & $0.8 \pm 0.2$ & $8 \pm 3$ & $5.8 \pm 1.7$ & $10 \pm 3$ \\
\hline Loam & 19 & $5.1 \pm 0.2$ & $0.8 \pm 0.2$ & $22 \pm 3$ & $10.1 \pm 2.0$ & $15 \pm 4$ \\
\hline Silt & 19 & $5.5 \pm 0.4$ & $0.4 \pm 0.1$ & $21 \pm 3$ & $6.8 \pm 2.0$ & $19 \pm 4$ \\
\hline Clay loam & 17 & $5.1 \pm 0.5$ & $0.9 \pm 0.5$ & $42 \pm 5$ & $16.2 \pm 2.7$ & $26 \pm 9$ \\
\hline Silty clay & 32 & $5.5 \pm 0.3$ & $0.6 \pm 0.2$ & $46 \pm 3$ & $15.4 \pm 2.7$ & $39 \pm 8$ \\
\hline Heavy clay & 37 & $6.0 \pm 0.2$ & $0.5 \pm 0.1$ & $76 \pm 3$ & $27.2 \pm 2.7$ & $42 \pm 6$ \\
\hline
\end{tabular}

* Mean with the confidence limits at the 95 per cent level

to be of the same order in the surface samples of sand, loam and silt soils on the one hand, and in the three groups of clay soils on the other hand. The corresponding contents of exchangeable potassium are lower in the samples of deeper layers than in those of the surface soils, except in the class of heavy clay. The average fixation of applied potassium under "wet conditions" tends to increase with an increase in the clay content, but this dependence does not seem to be close. In a previous study 
Table 2. Nonexchangeable potassium $(\mathrm{K} \mathrm{mg} / 100 \mathrm{~g})$ released by acid from soils of different texture.

\begin{tabular}{|c|c|c|c|c|}
\hline \multirow[t]{2}{*}{ Textural class } & \multicolumn{2}{|c|}{ Surface samples } & \multicolumn{2}{|c|}{ Subsoil samples } \\
\hline & Mean* & Range & Mean* & Range \\
\hline Sand, fine sand & $95 \pm 26$ & $4-399$ & $94 \pm 20$ & $1-280$ \\
\hline Loam & $165 \pm 31$ & $47-370$ & $283 \pm 51$ & $79-457$ \\
\hline Silt & $195 \pm 52$ & $76-545$ & $321 \pm 76$ & $181-682$ \\
\hline Clay loam & $258 \pm 32$ & $104-459$ & $404 \pm 56$ & $117-581$ \\
\hline Silty clay & $283 \pm 43$ & $95-525$ & $535 \pm 53$ & $336-820$ \\
\hline Heavy clay & $345 \pm 126$ & $119-647$ & $580 \pm 37$ & $308-827$ \\
\hline
\end{tabular}

* with the confidence limits at the 95 per cent level

(KAILA 1965) it was found that the total linear correlation coefficient between the fixation and the content of finer clay, less than $0.6 \mu$, was only $\mathrm{r}=0.52^{* * *}$, and with the coarser clay fraction it was even lower, or $\mathrm{r}=0.38^{* * *}$.

Data in Table 2 show that the average release of nonexchangeable potassium by the acid treatment also tends to be the higher the higher the clay content of the textural class is. Yet, variation in each group is large, and the ranges of all other groups are overlapping, except those of sand and fine sand soils with silty clay and heavy clay soils of deeper layers. The mean values indicate that the release of potassium from sand and fine sand soils is significantly lower than from the soils of the other textural classes. Among the subsoil samples, the mean values of the silty clay and heavy clay soils are significantly higher than those of the other groups. The lowest value in the surface samples is $4 \mathrm{mg} \mathrm{K} / 100 \mathrm{~g}$ in a sand soil and the highest $647 \mathrm{mg} \mathrm{K} / 100 \mathrm{~g}$ in a heavy clay soil. The minimum in the subsoils is also found in a sand soil, only $1 \mathrm{mg} / 100 \mathrm{~g}$, and the maximum in a heavy clay soil, $827 \mathrm{mg} / 100 \mathrm{~g}$, but also the highest value in the silty clay samples is almost the same or $820 \mathrm{mg} / 100 \mathrm{~g}$. Only five sub soil samples in the group of heavy clay released less than $500 \mathrm{mg} \mathrm{K} / 100 \mathrm{~g}$, and in six subsoil samples in the group of silty clay the release was less than $400 \mathrm{mg}$ $\mathrm{K} / 100 \mathrm{~g}$.

On the whole, the amounts of nonexchangeable potassium extracted by acid tend to be high in the present material as compared with data reported in other countries. Using the same method, SснаснтsснавEL (1961) found in surface samples of 75 loess soils (about 10 to 30 per cent clay) 25 to $90 \mathrm{mg} \mathrm{K} / 100 \mathrm{~g}$, and in 38 samples of marsh soils (about 15 to 60 per cent clay) approximately 35 to $100 \mathrm{mg} \mathrm{K} / 100 \mathrm{~g}$. Semb and Uhlen (1955) obtained by the boiling $\mathrm{HNO}_{3}$ extraction average contents of $130 \mathrm{mg} \mathrm{K} / 100 \mathrm{~g}$ in clay and clay loam soils, $64 \mathrm{mg} / 100 \mathrm{~g}$ in silt soils, and $50 \mathrm{mg} /$ $100 \mathrm{~g}$ in loamy till soils. The amounts extracted by STÅHLBERG (1960) from 131 plough layer samples of Swedish soils by boiling for ten minutes in $1 \mathrm{~N} \mathrm{HCl}$ are also lower than the present results, or from 7 to $195 \mathrm{mg} \mathrm{K} / 100 \mathrm{~g}$ in soils containing less than 25 per cent clay, and from 33 to $470 \mathrm{mg} / 100 \mathrm{~g}$ in samples with more than 25 per cent clay.

If the 135 samples of plough layer of the present material are classified on basis 
of their content of nonexchangeable acid soluble potassium into the potassium reserve classes used in Swedish soil survey (WIKLANDER 1958), the distribution will be the following:

\begin{tabular}{lccccc}
\multicolumn{1}{r}{ mg K/100g } & 1 & 2 & 3 & 4 & 5 \\
& $<50$ & $51-100$ & $101-200$ & $201-400$ & $>400$ \\
Fine sand soils & 6 & 7 & 14 & 1 & - \\
Loam soils & - & 6 & 15 & 7 & - \\
Silt soils & - & 3 & 10 & 1 & 1 \\
Clay loam soils & - & - & 8 & 20 & 1 \\
Silty clay soils & - & 2 & 4 & 16 & 5 \\
Heavy clay soils & - & - & 1 & 5 & 2 \\
All samples & 6 & 18 & 52 & 50 & 9
\end{tabular}

Thus, only 17 per cent of the samples belong to the classes 1 and 2 , while in a material of 67 samples of Swedish soils studied by WIKLANDER (1958), 39 per cent of the soils got into these lowest classes. On the other hand, in the present material, there are some samples even in the highest class which in WIKLANDER's material contained none. Because about one half of the surface samples of virgin soils in the present material are sand soils, more than 40 per cent of them fall into the lowest class, but there are also almost 40 per cent of virgin samples in the two highest classes.

The relationship between the content of clay and the release of nonexchangeable potassium is not particularly close in the present material: the total linear correlation coefficient between the fraction less than $2 \mu$ and the quantities of potassium released is $\mathrm{r}=0.74^{* * *}$. This is almost equal to the corresponding value found by SchaснтsсHABEL (1961) for the marsh soils analysed. In loess soils with a narrower range of variation in the clay content he got a lower coefficient, $r=0.59 * * *$ which is of the same order as the figure calculated for the 178 non-clay samples of the present material, or $\mathrm{r}=0.51^{* * *}$, and for the 152 clay samples, or $\mathrm{r}=0.52^{* * *}$. There seems to be no connection between the nonexchangeable potassium and the content of coarser clay $(2-0.6 \mu)$ in these clay soil samples; $r=0.27^{* *}$. A low correlation, $\mathrm{r}=0.42^{* * *}$, was found between the nonexchangeable potassium and the content of finer clay, less han $0.6 \mu$.

There is supposed to be an equilibrium between the exchangeable potassium and the more readily releaseable nonexchangeable potassium in soils. Yet, only seldom the correlation between these fractions of potassium appears to be close. Coefficients as low as about 0.3 was found by SEmb and UhleN (1955) and about 0.4 by Schachtschabel (1961). In sand and moraine soils poor in potassium WiKLANDER (1960) found an exceptionally close dependence between exchangeable and nonexchangeable potassium: the correlation coefficient for the subsoil samples was as high as $0.89^{* * *}$, but in the plough layer the correlation was markedly lower, or $\mathrm{r}=$ $0.61^{* * *}$. In the present material the relationship between the contents of readily exchangeable and acid soluble nonexchangeable potassium is characterized by the following correlation coefficients in 


$\begin{array}{lccc} & \text { non-clay soils } & \text { clay soils } & \text { all soils } \\ \text { surface samples } & 0.19 & 0.42^{* * *} & 0.46^{* * *} \\ \text { subsoil samples } & 0.24^{*} & 0.30^{* *} & 0.64^{* * *} \\ \text { all samples } & 0.09 & 0.17^{*} & 0.43^{* * *}\end{array}$

Thus the correlation is rather low or there is no correlation between these somewhat vague fractions of potassium, except in the group of all subsoil samples. Yet, it is likely that this correlation is mainly caused by the fact that both the contents of exchangeable and nonexchangeable potassium are to a certain extent connected with the clay content.

Also the fixation of added potassium tends to be higher in clay soils than in soils of a coarser texture. Therefore, it is not surprising that, if there is any correlation between the fixation of added potassium and the content of nonexchangeable potassium, the correlation will be positive. This can be seen from the following correlation coefficients between these variables in different groups of samples:

$\begin{array}{lccc} & \text { non-clay soils } & \text { clay soils } & \text { all soils } \\ \text { surface samples } & 0.13 & 0.16 & 0.37 * * * \\ \text { subsoil samples } & 0.45^{* * *} & 0.35^{* *} & 0.65^{* * *} \\ \text { all samples } & 0.37^{* * *} & 0.55^{* * *} & 0.65^{* * *}\end{array}$

Elimination of the effect of the clay content decreases the correlation between the fixation and the content of nonechangeable potassium, e.g. the partial correlation coefficient for the total material is only 0.36 .

According to data reported in a previous paper (KAILA 1967), nonexchangeable potassium released from separated mechanical fractions by a somewhat milder acid treatment than that used in the present study ranged from 5 to 24 per cent of the total potassium content in the clay fraction, from 3 to 16 per cent of that in the silt fraction, and from less than 1 per cent to 7 per cent in the fine sand material. In soil samples the part of nonexchangeable acid-soluble potassium calculated as a percentage of the total potassium content of the soil is not likely to exceed these limits to any marked degree. In some soils of the present study the following ranges and approximate mean values were found:

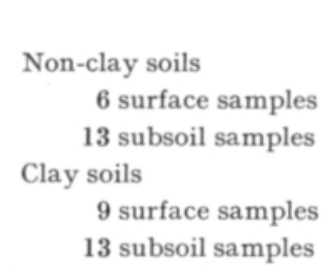

Nonexchangeable $\mathrm{K}$ per cent of total $\mathrm{K}$

The particularly large variation in the non-clay samples is due to some coarse sand soils on the one hand, and to samples of a virgin silt soil rich in mica, on the other hand. Without these silt samples the nonexchangeable potassium in the non-clay soils does not exceed 8.9 per cent of the total potassium content of the surface samples and 10.9 per cent of that in the subsoil samples. 
According to the figures in Table 2, the mean content of nonexchangeable acidsoluble potassium in loam, clay loam, silty clay and heavy clay soils seems to be significantly higher in the subsoil samples than in the surface soil samples. When layers of cultivated soils down to $60-70 \mathrm{~cm}$ were compared, it was found that, usually, nonexchangeable acid-soluble potassium was at its lowest in the plough layer and tended to increase with the depth, although nor regularly. This increase may be often connected with an increase in the clay content. The occurrence of a minimum in the plough layer is likely to be due to the higher content of organic matter and to the more advanced state of weathering of the minerals in it as compared with the deeper layers.

Soil formation also exerts its effect on soil potassium status. Results obtained for a fairly well-developed podsol on moraine soil in east Finland are reported in

Table 3. Potassium status in a podsol soil and a brown podsolic soil.

\begin{tabular}{|c|c|c|c|c|c|}
\hline $\begin{array}{l}\text { Depth } \\
\mathrm{cm}\end{array}$ & $\mathrm{pH}$ & $\begin{array}{c}\text { Org. C } \\
\%\end{array}$ & $\begin{array}{c}\text { Exchangeable } \\
\mathrm{mg} / 100 \mathrm{~g}\end{array}$ & $\begin{array}{l}\text { exchangea } \\
\mathrm{mg} / 100 \mathrm{~g}\end{array}$ & $\begin{array}{l}\text { tion of } \mathrm{K} \\
\%\end{array}$ \\
\hline \multicolumn{6}{|l|}{ Podsol soil } \\
\hline $0-10$ & 3.8 & 9.8 & 18 & 18 & 8 \\
\hline $10-18$ & 4.4 & 0.8 & 1 & 3 & 14 \\
\hline $20-30$ & 5.3 & 0.9 & 2 & 44 & 7 \\
\hline $40-50$ & 5.3 & 0.3 & 2 & 128 & 4 \\
\hline \multicolumn{6}{|c|}{ Brown podsolic soil } \\
\hline $0-10$ & 4.7 & 8.4 & 8 & 27 & 14 \\
\hline $10-20$ & 4.6 & 3.2 & 6 & 29 & 14 \\
\hline $20-30$ & 4.5 & 1.0 & 3 & 20 & 8 \\
\hline $30-40$ & 4.5 & 0.3 & 2 & 15 & 5 \\
\hline
\end{tabular}

Table 3. For the sake of comparison, the corresponding test values for a moraine soil under hazel trees in south Finland are recorded. This soil may be called humus rich brown podsolic soil (cf. TAVERNIER and SMITH 1957).

Owing to the high content of poorly humified organic matter in the $A_{0}-A_{1}$ layer $(0-10 \mathrm{~cm})$ of the podsol soil, its weight of volume is low and the value for the content of readily exchangeable potassium is exceptionally high. The latter drops sharply in the horizon $\mathrm{A}_{2}(10-18 \mathrm{~cm})$ without any significant increase in the deeper layers $\mathrm{B}(20-30 \mathrm{~cm})$ and $\mathrm{C}(30-40 \mathrm{~cm})$, as is the case in regard to the nonexchangeable acid-soluble potassium which also has a very low minimum in the eluvial layer. The fixation of added potassium, on the other hand, is highest in the eluvial horizon and decreases downwords. Thus the potassium status is poorest in the $\mathbf{A}_{\mathbf{2}}$-horizon, although not particularly good in the illuvial layer. In the brown podsolic soil with no definite $\mathrm{A}_{2}$-horizon the test values are rather low and tend to decrease with the depth fairly regularly.

Nonexchangeable acid-soluble potassium in virgin soils is native potassium, but in cultivated soils a part of it may originate from fertilizer potassium fixed by the 
soil. In order to study the fate of applied potassium in some soils, samples from a laboratory experiment were analysed. These samples were incubated for three months at room temperature without any application, or with an addition of $2.5 \mathrm{me} \mathrm{K} / 100 \mathrm{~g}$ of soil. Before the samples were analysed for their contents of readily exchangeable potassium and acid soluble potassium, they were air-dried and ground to pass $2 \mathrm{~mm}$ sieve.

Table 4. Recovery of applied potassium.

\begin{tabular}{|c|c|c|c|c|c|c|c|c|c|c|c|c|}
\hline & & \multirow{3}{*}{$\begin{array}{c}\text { Depth } \\
\mathrm{cm}\end{array}$} & \multirow{3}{*}{$\mathrm{pH}$} & \multirow{3}{*}{$\begin{array}{c}\text { Org. C } \\
\%\end{array}$} & \multirow{3}{*}{$\begin{array}{c}\text { Clay } \\
\%\end{array}$} & \multirow{3}{*}{$\begin{array}{c}\text { Silt } \\
\%\end{array}$} & \multirow{3}{*}{$\begin{array}{c}\text { Tot. K } \\
\%\end{array}$} & \multirow{3}{*}{\multicolumn{2}{|c|}{$\begin{array}{r}\text { Exch. Non- } \\
\text { exch. } \\
\text { K mg/100 g }\end{array}$}} & \multicolumn{3}{|c|}{ Per cent of applied $\mathrm{K}$} \\
\hline & & & & & & & & & & \multicolumn{2}{|c|}{ recovered as } & \multirow[t]{2}{*}{ not recovered } \\
\hline & & & & & & & & & & exch. K & $\begin{array}{l}\text { non- } \\
\text { xch. K }\end{array}$ & \\
\hline \multirow[t]{3}{*}{ HP } & la & $0-20$ & 6.1 & 2.5 & 18 & 68 & 2.61 & 5 & 170 & 20 & 53 & 27 \\
\hline & b & $30-40$ & 5.8 & 1.1 & 18 & 80 & 2.78 & 5 & 190 & 18 & 50 & 32 \\
\hline & c & $50-60$ & 6.0 & 0.1 & 14 & 66 & 2.78 & 4 & 220 & 17 & 41 & 42 \\
\hline \multirow[t]{3}{*}{ HP } & $2 \mathrm{a}$ & $0-20$ & 5.8 & 2.2 & 16 & 68 & 2.56 & 10 & 150 & 56 & 36 & 8 \\
\hline & b & $30-40$ & 6.0 & 0.5 & 8 & 74 & 2.77 & 3 & 190 & 23 & 41 & 36 \\
\hline & c & $50-60$ & 6.2 & 0.6 & 17 & 78 & 2.80 & 5 & 260 & 9 & 46 & 45 \\
\hline \multirow[t]{3}{*}{$\mathrm{HP}$} & $3 \mathrm{a}$ & $0-20$ & 5.1 & 2.3 & 30 & 39 & 2.54 & 19 & 150 & 64 & 30 & 6 \\
\hline & b & $30-40$ & 4.9 & 1.3 & 28 & 48 & 2.68 & 9 & 170 & 85 & 5 & 10 \\
\hline & c & $50-60$ & 5.0 & 0.2 & 36 & 58 & 3.08 & 9 & 360 & 19 & 38 & 43 \\
\hline
\end{tabular}

Data in Table 4 characterize the original samples and the recovery of added potassium from these silt and silty clay soils. The recovery was calculated on basis of comparison between the corresponding potassium contents of samples treated with potassium and samples without potassium treatment. This means that it was supposed that the changes in the soil potassium due to incubation would be similar in spite of the application of potassium. This, of course, is not sure, and the results must be examined without forgetting it.

In the original samples the total potassium content ranges from 2.54 to 3.08 per cent, the content of readily exchangeable potassium is rather low even in the plough layer, and also their content of acid soluble nonexchangeable potassium is markedly smaller than the mean values of the silt and silty clay soils in Table 2 are. The apparent recovery of added potassium varies markedly in these nine samples. As much as 85 per cent of the applied potassium was extracted by ammonium acetate from the silty clay subsoil sample HP $3 \mathrm{~b}$, but only 9 per cent from the silt sample HP 2c. It is of interest to note that a considerable part of the added potassium seems to be bound by the soil samples in such way that it has not been released by the acid extraction. Thus, in the deepest layers of all soils, more than 40 per cent of added potassium remains in the samples after the extraction with acid, and even from the layer 30 to $40 \mathrm{~cm}$ in silt soils HP 1 and HP 2 more than 30 per cent was not recovered. The part of applied potassium found in the acid-soluble nonexchangeable 
form is large in all other samples than the silt soil HP $3 \mathrm{~b}$ with a low capacity to fix potassium.

WooD and DeTURK (1941) also found that a large part of applied potassium could be retained as potassium not extracted by boiling $1 \mathrm{~N} \mathrm{HNO}_{3}$. They observed that the proportion of added potassium which remained soluble in acid was growing with increasing additions, and they supposed that the capacity for retaining potassium in this form is definitely limited and therefore appears to be to some degree analogous to the cation exchange capacity of a soil.

\section{Discussion}

The "more readily available nonexchangeable potassium" represents a rather indefinite fraction of soil potassium. Its level will depend not only on the mineralogy of the soil, the grade of weathering and the potassium content of the minerals, but also on the crops and their ability to take up potassium under the conditions of the growing season. As far as the results of the present study are or the same order as the actual content of "nonexchangeable but useful" potassium, it seems that Finnish mineral soils contain fairly large reserves of potassium.

In practice, these potassium reserves are utilized to certain extent. Usually, the amount of potassium in the fertilizers recommended to clay and silt soils is lower than the quantities taken up by crops. Significant potassium effect is expected when clay is added to peat soils, and if sand rich in mica is available, even its application may considerably reduce the need of potassium fertilizers on a peat soil. Yet, it seems that seldom the native potassium sources even in clay soils will be mobilized at such speed that they can continuously support crops without drop in the level of yields.

There is supposed to be an equilibrium in soil between the potassium fractions:

$\mathrm{K}$ in solution $\rightleftarrows$ exchangeable $\mathrm{K} \rightleftarrows$ nonexchangeable $\mathrm{K}$

This means that release of nonexchangeable $\mathrm{K}$ will dominate only when the soluble and exchangeable fractions are low. It is known that, micas are very sensitive in this respect, and that the presence of potassium in solution readily reduces the rate of diffusion of nonexchangeable potassium to solution (RAUSELL-CoLOM et al. 1965). Thus application of potassium fertilizers is likely to prevent mobilization of native potassium sources, and even to result in some fixation of fertilizer potassium. On the other hand, depletion of available soil potassium by crops may decrease the level of potassium so much that diffusion of nonechangeable potassium to solution will become dominant. There are differences in the ability of crops to utilize nonexchangeable potassium (Drake and SCARSETh 1939, Evans and AtToE 1948), and it may be supposed that these differences partly depend on the level to which plant roots are able to deplete potassium in solution and on the exchange sites, without any serious disturbance in their development.

It was found that the same soil samples are effective both in fixing of applied potassium and in releasing potassium from nonexchangeable forms. This apparent disagreement can be explained on basis of the fact that the potassium concentrations of the solutions around the soil particles are quite different by the determinations of these characteristics, and this makes the conditions suitable either to fixation or to mobilization of potassium. It is also possible that there are in the same 
mineral particles some sites which are able to fix and other sites which are able to release potassium.

In the present study no particular attention was paid to the mineralogy of the soil samples. According to the more or less qualitative information about the minerals in clay and silt fractions in part of the present material, samples which released high amounts of nonexchangeable potassium were rich in mica and micaceous minerals. In some soils the lower content of nonexchangeable acid-soluble potassium in the surface layer than in the deeper layers can be attributed to the more advanced state of weathering of the micaceous minerals of the surface soil. In addition to micas and mainly trioctahedral illites, potassium containing minerals usually found in Finnish soils are potassium feldspars and vermiculite, and some mixed layer clay minerals (SOVERI 1956, Soveri and HyYpPÄ 1966). It is not known how effective the acid treatment is in releasing of potassium from these minerals. According to results obtained by boiling $1 \mathrm{~N} \mathrm{HCl}$ (STÅHLBERG 1960), biotite will release more than 90 per cent of its potassium provided the material is as fine as finer silt, muscovite will release only about 4 per cent, and microcline less than 2 percent. Vermiculite also releases its potassium readily by boiling acid (LEAF 1959).

ARNold and CLOSE (1962) claim that the main reason for variation in the potassium releasing powers of the soils are differences in the amount and potassium content of the finer clay fractions. This may be true, but it seems as if some attention must be paid even to the silt fraction. Amounts of nonexchangeable potassium which may be extracted by acid from silt fraction are found to be more than one half of those extracted from clay material of the same samples (KAILA 1967). In the present study, several soils poor in clay but rich in silt had a considerable content of nonexchangeable acid-soluble potassium.

\section{S $u m$ mary}

Release of nonexchangeable potassium by treatment with $1 \mathrm{~N} \mathrm{HCl}$ at $50^{\circ} \mathrm{C}$ was studied on basis of a material consisting of 330 samples of Finnish mineral soils.

The results ranged from 1 to $830 \mathrm{mg} \mathrm{K} / 100 \mathrm{~g}$. The mean content of nonexchangeable acid-soluble potassium was in the surface samples of sand and fine sand soils $95 \pm 26 \mathrm{mg} / 100 \mathrm{~g}$, in loam soils $165 \pm 31 \mathrm{mg} / 100 \mathrm{~g}$, in silt soils $195 \pm 52 \mathrm{mg} / 100 \mathrm{~g}$, in clay loam soils $258 \pm 32 \mathrm{mg} / 100 \mathrm{~g}$, in silty clay soils $283 \pm 43 \mathrm{mg} / 100 \mathrm{~g}$, and in heavy clay soils $345 \pm 126 \mathrm{mg} / 100 \mathrm{~g}$. In the subsoil samples of loam, clay loam, silty clay and heavy clay soils the mean content was significantly higher than in the surface samples, or $283 \pm 51 \mathrm{mg} / 100 \mathrm{~g}, 404 \pm 56 \mathrm{mg} / 100 \mathrm{~g}, 535 \pm 53 \mathrm{mg} / 100 \mathrm{~g}$, and $580 \pm 37$ $\mathrm{mg} / 100 \mathrm{~g}$, respectively. The results seem to be high as compared with data reported from Sweden, Norway and Germany.

The content of nonexchangeable potassium released by acid was to some extent connected with the clay content: the correlation coefficient in the whole material was $r=0.74^{* * *}$, but only about $0.5^{* * *}$ both in the separate groups of the 178 nonclay samples and the 152 clay samples.

There was only a very low correlation between the contents of nonexchangeable acid-soluble potassium and readily exchangeable potassium. A somewhat higher 
correlation, $\mathrm{r}=0.65^{* * *}$, was found for the relationship between the former and fixation of added potassium under "wet" conditions, but it was markedly decreased by the elimination of the effect of the clay content.

Nonexchangeable acid-soluble potassium usually represented a lower part of the total potassium in the surface samples than in the subsoil samples, and also the proportion tended to be higher in the clay soils than in the coarser soils. It varied from 0.2 to 26.3 per cent in the small material studied.

In most cultivated soils less nonexchangeable potassium was released from the samples of plough layer than from samples of deeper layers. In a podsol profile the minimum content of nonexchangeable and exchangeable potassium and the maximum of fixation of added potassium was found in the $\mathrm{A}_{2}$ horizon; in a brown podsolic soil all these test values decreased fairly regularly with depth.

From some silt and silty clay soils incubated for three months at room temperature a large part, even more than 40 per cent of the added potassium was not recovered by the acid extraction. Ammonium acetate extracted from 9 to 85 per cent of the potassium applied before incubation, and the part of added potassium found as nonexchangeable acid-soluble form varied from 5 to 53 per cent.

The equilibrium between the different potassium fractions in soil was discussed. It was supposed that differences in the ability of plants to utilize nonexchangeable potassium may partly depend on the level to which plant roots are able to decrease potassium concentration in the solution around the minerals.

\section{REFERENCES}

Abel, F. A. E. \& Magistad, O. C. 1935. Conversion of soil potash from the non-replaceable to the replaceable form. Amer. Soc. Agron. J. 27: 437-445.

ARnold, P. W. 1960. Nature and mode of weathering of soil-potassium reserves. J. Sci. Fd. Agric. 11: $285-292$.

- $-\&$ Close, B. M. 1961. Release of non-exchangeable potassium from some British soils cropped in the glasshouse. J. Agric. Sci. 57: 295-304.

Breland, H. L. \& Bertramson, B. R. \& Borland, J. W. 1950. Potassium-supplying power of several Indiana soils. Soil Sci. 70: $237-247$.

Drake, M. \& Scarseth, G. D. 1940. Relative abilities of different plants to absorb potassium and the effects of different levels of potassium on the absorption of calcium and magnesium. Soil Sci. Soc. Amer. Proc. 4: 201-204.

EGNER, H. 1954. Neue Beiträge zur chemischen Bodenuntersuchungen unter besonderer Berücksichtigung der Laktatmethode. Landw. Forsch. 6. Sonderh.: 28-32.

Gholston, L. E. \& Hoover, C. D. 1949. The release of exchangeable and nonexchangeable potassium, from several Missisippi and Alabama soils upon continuous cropping. Soil Sci. Soc. Amer. Proc. 13: $116-121$.

KAllA, A. 1965. Fixation of potassium in Finnish soils. J. Sci. Agr. Soc. Finland 37: 116-126.

- 1967. Potassium status in different particle size fractions of some Finnish soils. Ibid. 39: 45-56.

Keränen, T. 1946. Kaliumista Suomen maalajeissa. Summary: On potassium in Finnish soils. Acta Agr. Fennica 63, 114 p.

LeAf, A. L. 1959. Release of potassium from feldspathic rock and minerals. Soil Sci. 87: 11-12.

Rausell-Colom, J. A. \& Sweatman, T. R. \& Wells, C. B. \& Norrish, K. 1965. Studies in the artificial weathering of mica. In Experimental Pedology p. 40-72, London 1965.

Reitemeier, R. F. \& Holmes, R. S. \& Brown, I. C. etc. 1948. Release of nonexchangeable potassium by greenhouse, Neubauer, and laboratory methods. Soil Sci. Soc. Amer. Proc. 12: 158-162. 
Rouse, R. D. \& Bertramson, B. R. 1949. Potassium availability in several Indiana soils. Ibid. 14: $113-123$.

Schachtschabel, P. 1937. Aufnahme von nicht-austauschbarem Kali durch die Pflanzen. Bodenk.u. Pflanzenern. 3: 107-133.

- 1961. Fixierung und Nachlieferung von Kalium- und Ammonium-Ionen. Landw. Forsch. 15. Soderh.: $29-47$.

Schmitz, G. W. \& PRATt, P. F. 1953. Exchangeable and nonexchangeable potassium as indexes to yield increases and potassium absorption by corn in the greenhouse. Soil Sci. 78: $\mathbf{3 4 5}-\mathbf{3 5 3}$.

SEMB, G. \& UhLEN, G. 1955. A comparison of different analytical methods for the determination of potassium and phosphorus in soil based on field experiments. Acta Agr. Scand. V: 44-68.

Soveri, U. 1956. The mineralogical composition of argillaceous sediments of Finland. Ann. Acad. Scient. Fenn. A III 48.

- \& HYYPPÄ, J. M. I. 1966. On the mineralogy of fine fractions of some Finnish glacial tills. State Inst. Tech. Res. Finland, Publ. 113.

Stanton, D. A. \& Orchard, E. R. 1963. Evaluation of the potassium-supplying power of soils. S. afr. J. Agric. Sci. 6: 249-260.

Stewart, E. H. \& Volk, N. J. 1946. Relation between potash in soils and that extracted by plants. Soil Sci. 61: 125-129.

StÅhlberg, S. 1960. Studies on the release of bases from minerals and soils III. Acta Agr. Scand. X: $185-204$.

Tavernier, R. \& Smith, G. D. 1957. The concept of Braunerde (Brown Forest soil) in Europe and the United States. In Adv. Agronomy IX: 216-289.

Wiessmann, H. \& Lehmann, W. 1934. Untersuchungen über die Kationen-, insbesondere Kaliumaufnahme durch die Pflanzen. Zeitschr. Pflanzenern. Düng. Bodenk. 35(A): 129-140.

WIKLANDER, L. 1958. Kalkens markeffekt. II. Grundförbättr. 4: 203-224.

- 1960. Kalium i skånska ákerjordar. Socker. Handl. I, 16: 51-63.

Wood, L. K. \& DETURK, E. E. 1941. The absorption of potassium in soils in nonreplaceable forms. Soil Sci. Soc. Amer. Proc.: 5: 152-161.

\section{SELOSTUS:}

KIVENNÄISMAITTEMME HAPPOON LIUKENEVASTA VAIHTUMATTOMASTA KALIUMISTA

Armi Kaila

Yliopiston Maanviljelyskemian laitos, Viikki

Tutkimuksessa määritettiin 330 näytteestä $1 \mathrm{n}$ suolahappoon $50^{\circ} \mathrm{C}$ :ssa liukeneva vaihtumaton kalium, jonka katsotaan vastaavan maan enemmän tai vähemmän käyttökelpoisia kaliumin reservejä. Tulokset vaihtelivat $1-830 \mathrm{mg} \mathrm{K} / 100 \mathrm{~g}$. Keskimääräinen pitoisuus lisääntyi hiekka- ja hietamaista saviin ja oli yleensä matalampi pintamaitten kuin syvempien kerrosten näytteissä. Tulokset olivat korkeammat kuin eräät Ruotsin, Norjan tai Saksan maista esitetyt.

Vaihtumattoman happoon liukenevan kaliumin pitoisuus riippui jossain määrin maan saveksen pitoisuudesta, korrellaatio vaihtuvan kaliumin pitoisuuden kanssa oli hyvin heikko, ja vuorosuhde kaliumin pidätyskyvyn kanssa näytti johtuvan molempien näiden muuttujien riippuvuudesta saveksen pitoisuudesta.

Happo näytti uuttavan suuremman osan savimaitten kuin karkeampien maitten kokonaiskaliumista, samoin suuremman osan syvempien kerrosten kuin pintamaitten kokonaiskaliumista.

Viljelysmaissa muokkauskerros sisälsi yleensä vähiten happoon liukenevaa vaihtumatonta kaliumia. Podsolimaassa oli sekä vaihtuvan että vaihtumattoman kaliumin minimi ja pidättymisen maksimi $\mathrm{A}_{2}$-tasossa, Ruskomaan kaltaisessa maassa arvot alenivat tasaisesti syvemmälle mentäessä.

Muhituskokeessa todettiin, että melkoinen osa, jopa yli $40 \%$ eräisiin hiesu- ja hiesusavinäytteisiin lisätystä kaliumista pidättyi happoon liukenemattomaksi. Veteenliukenevaksi ja vaihtuvaksi jäi $9-$ $85 \%$ ja happoon liukenevaan vaihtumattomaan fraktioon joutui $5-53 \%$. 